\title{
AN ANNOTATED BIBLIOGRAPHY OF MANUEL BRETÓN DE LOS HERREROS
}

Gerard Flynn

Introduction.

The past criticism of Manuel Bretón de los Herreros (1796-1873) falls roughly into two parts: nineteenth century essays, which consist for the most part of generalities, and the studies of the last thirty years, beginning with Charles B. Qualia's article of 1941 and the Berceo articles of 1947. Between these two temporal divisions appear Georges Le Gentil's masterly work of 1909, the negative criticism of Arozín in 1916, and the derogatory criticism of Carmen de Burgos in 1919; Azorín's negative remarks, alongside changing tastes, may have accounted for the critical drought in the decades preceding the Second World War. As with most nineteenth-century playwrights, the criticism of Bretón's theater has been in comparatively short supply.

A list of Bretón's plays will run to some 177 items, consisting of 103 original titles, ten adaptations of Golden Age comedias, and sixty-four translations, two from the Italian and the rest from the French. These plays are listed by Bretón's nephew, Cándido Bretón y Orozco, in his introduction to volume I of the Obras completas (Madrid: Imprenta de Miguel Ginesta, 1883), which appears under Primary Sources, below.

I hope that the present bibliography will serve as a starting-point for the increased study of Spain's finest comediographer in the nineteenth century, and also for the study of the nineteenth-century theater in general.

\section{Primary Sources.}

I. Editions of Bretón's Works. Collections, in chronological order.

Teatro. 6 volumes. Ed. José María Lafragua (México: Imprenta de Vicente García Torres, 1842-1843). Only volumes I and II have been available to me. No critic seems to have based his commentary on this edition. Lafragua's prologue states that he will publish every play of Bretón he can get his hands on, in chronological order. He promises no less than four plays nor more than six in each volume; since volumes I and II contain four plays each, it would seem that the six volume set contains about thirty plays of the "one hundred and thirty" Lafragua mentions as being extant in his day. . . . . . . This edition has two unusual features: (1) each play is followed by an Análisis, written by the editor; (2) the editor includes translations as well as original plays; volume I has Bretón's rendition of Racine's Andrómaca and of Le Franc de 
Pompignan's Dido; and volume II his rendition of Marivaux's Engañar con la verdad and of Scribe's El amante prestado. The prolongue is distinctive since Lafragua sees philosophical depth in Bretón, whereas others do not; he praises Bretón's creation of characters, whereas other nineteenth-century critics find him wanting in this respect.

Obras. 5 volumes (Madrid: Imprenta Nacional, 1850-1851). This edition has some 88 compositions in verse and 22 in prose not contained in later editions. It also contains the following plays, which are not to be found in the 1883 edition described below: A la vejez viruelas (Bretón's first play, written in 1817 and staged in 1824); Achaques a los vicios (his third play, written in 1825 and staged in 1830); El ingenuo (1828); $\mathbf{S i}$ no vieran las mujeres (1828, a refundición of a play by Lope de Vega); La falsa ilustración (1830); El regañón enamorado (1830, a translation of a play by Monvel); El segundo año (1832, a translation of Scribe); La familia del boticario (1832, a translation of Duvert); No más muchachos (1833, a translation of Scribe); Mérope, tragedia en tres actos (1835); La primera lección de amor (1837, a translation of Bayard); La pluma prodigiosa (1841, comedia de magia); and Fuego de Dios en el querer bien (1847, a refundición of a play by Calderón) - thirteen plays in all. . . . . This collection is important for five reasons: (1) it contains four of the six original plays belonging to Bretón's early (pre-Marcela, 1831) theater, which are not to be found in the 1883 edition; (2) it has two refundiciones of Lope and Calderón, whereas the 1883 edition has no refundiciones at all; (3) it has four translations from the French, whereas the 1883 edition has only two; (4) it has Bretón's comedia de magia, written in the fashion of Grimaldi's famous Pata de cabra, and this does not appear in the 1883 edition; (5) it has Mérope, Breton's "tragedy in three acts," which the reader will find is not really a tragedy.

Obras escogidas. 2 volumes (Paris: Baudry, 1853). This collection, with a prologue by Hartzenbusch, contains some important material not found in the 1883 edition of the Obras, namely, Bretón's book-length essay on the "Arte de la declamación en los teatros de España"; his play, Cuidado con las amigas; several letrillas, redondillas, romances, romancillos, anacreónticos, and one article in prose, "Una nariz, anécdota de carnaval." The "Arte de la declamación..." is discussed in the third section of this Bibliography.

Obras. 5 volumes (Madrid: Imprenta de Miguel Ginesta, 1883-1884). The best known collection of Bretón's works. The first volume includes a seventeen-page introduction and also a catalogue of Bretón's works by his nephew, Cándido Bretón y Orozco. It also has the prologue to the edition of 1850 by Juan Eugenio Hartzenbusch, and Bretón's own preface, written before his death in 1873 . This is the edition that Bretón himself preferred; thus it is his own doing that all refundiciones, most translations (there are only two), and certain plays are omitted... Cándido Bretón lists in the catalogue a total of 103 original plays, 10 refun iciones, and 64 translations; about three-fifths of the original plays appear in this collection. 
Teatro. Prólogo y notas de Narciso Alonso Cortés. In Clásicos castellanos, vol. 92 (Madrid: Espasa-Calpe, 1943). Contains two of Bretón's most famous plays, Muérete iy verás! and El pelo de la dehesa.

Obra dispersa. Tomo I. El Correo Literario y Mercantil. Edición y estudio de J. M. Díez Taboada y J. M. Rozas (Logroño: Instituto de Estudios Riojanos, Imprenta Moderna, 1965). This volume contains the criticism of books and plays, and also some costumbrista articles, that Bretón wrote between 1831 and 1833 for the tri-weekly paper, El Correo Literario y Mercantil. Helps the reader understand Bretón's aesthetics. The editors wrote a prologue called "Crítico Teatral." Has an onomastic index. A private communication from Logroño states that Volumes II and III have not appeared and probably will not appear. Volume II had been planned for the articles Bretón wrote for other journals, and Volume III for his poetry not appearing in other collections.

\section{Editions of Bretón's Works. Single Plays and Other Works.}

In addition to the bibliographies of the Bibliothèque Nationale, the British Museum, the Congressional Library, the Hispanic Institute, and the Union Catalogue, the interested reader might consult the following two reference works: Antonio Palau y Dulcet, Manual del librero hispanoamericano, Tomo segundo (Barcelona: A. Palau, 1949), 395-396, and José Simón Díaz, Manual de bibliografía de la literatura española, 2a. ed. (Barcelona: Editorial Gustavo Gili, 1966), p. 357.

All but five of the works listed below do not appear in the 1842,1850,1853, and 1883 collections of Bretón's plays.

A la vejez viruelas. Comedia original en tres actos (Madrid: Imprenta de Miguel de Burgos, 1825). There is a variation between the 1825 text, the first edition, and the play as it appears in volume I of the 1850 edition: see the Escena última of both editions. The word escándalo of the 1850 edition does not appear in the 1825 edition and suggests a moralizing attitude: the year 1850 coincides with the beginning of the alta comedia. (This play also appears in Obras 1850.)

El amante prestado. Comedia en un acto (Madrid: Imprenta de Cipriano López, 1857). "Freely translated from the French" of Scribe, and first staged in Seville in 1830.

Cosas de Don Juan. Zarzuela en tres actos. Música de Don Rafael Hernando (Madrid: Imprenta de C. González, 1854). One of four zarzuelas Bretón wrote. The other three are El novio y el concierto (one act), Los solitarios (one act), and El novio pasado por agua (three acts). Bretón wrote something in every kind of dramatic form, although he clearly preferred to write comedies.

Desconfianza y travesura, o, A la zorra candilazo (Madrid: Imprenta de Cipriano López, 1857). A one act play first staged in 1831 , "freely translated from the French" of Dieulafoy.

Desde Toledo a Madrid. Comedia del Maestro Tirso de Molina. Refundida y puesta en cinco actos (Madrid: Imprenta de S. Omaña, 1849). This adaptation of a Golden Age play was first staged in 1847 . 
El Ebro. Comedia en un acto. Escrita con el plausible motivo de inaugurarse la navegación de dicho río, canalizado desde San Carlos de la Rápita a Mequinenza (Madrid: Imprenta Nacional, 1857). A circumstantial piece, written on the opening of a new canal.

La Independencia. Edited by James Geddes, Grace E. Merrill, Bertha A. Merrill, and Joseph C. Palamountain (New York: Charles Scribners, 1924). A students' edition, with a prologue, a vocabulary solely in Spanish, exercises and notes. Has a useful bibliographical note on pages xvi-xvii. (This play also appears in Obras 1883.)

Las improvisaciones. Improvisación dramática para representarse en Madrid en el Teatro del Príncipe con el patriótico objeto de celebrar la heroica defensa y la salvación de la Invicta Bilbao (Madrid: Imprenta de los hijos de Doña Catalina Piñuela, 1837). A circumstantial one act play celebrating the entrance of Espartero into Bilbao on January 1, 1837. Don Homobono's long speech on pp. 22 and 23 is a scathing denunciation of Carlism.

La loca fingida, Drama en un acto (Madrid: Imprenta de Repullés, 1833). "Translated freely from the French;" the original author is not named.

Los carlistas en Portugal, o, La tremenda espedición. Desenfado dramático en un acto. A one act farse appearing in the newspaper El Universal, April 15, 1834, pp. 2-4. A Carlist prelate and three Carlist generals, one of them the famous Merino, appear as fools. The Carlist troops are a slovenly, disorderly lot.

Los sentidos corporales. Comedia en tres actos y en verso (Madrid: Imprenta de José Rodríguez, 1867). Bretón's last play, written when he was seventy-one years of age. Not included in Obras 1883.

Marcela, o ¿a cuál de los tres? Edited with introduction, notes and vocabulary by William S. Hendrix (New York: Benjamin H. Sanborn Co., 1922). A students' edition. Contains a biographical sketch, a list of the verse forms used in Marcela, and a bibliographical note.

Marcela o ¿a cuál de los tres? Edición e introducción de José Hesse (Madrid: Taurus Ediciones, 1969). The introduction rejects the idea of two stages in Bretón's theater, the Moratinian until 1831, and the Bretonian after 1831. Argues that Bretón never got away from his "neoclassical sediment." Maintains that the "Bretonian genre" seen by Eugenio Ochoa was "no more than the projection, on an unchangeable screen of neoclassical depth, of the new costumbrista models which Romanticism put in vogue." ... Also discusses Bretón's non-dramatic work. (Marcela is also in the Obras 1883.)

Mi empleo y mi muger. Comedia en tres actos (Madrid: Imprenta de D. León Aminta, 1835). "Translated freely from the French." Original author not given. This play may be found in the Jibrary of Princeton University in the book called Comedias varias, 31661 , 1999, v. 41, along with seven other representative plays of 1808-1835.

Mocedades. Comedia en tres actos. Original y en verso. (Madrid: Imprenta de José Rodríguez, 1857). 
El novio pasado por agua. Zarzuela de figurón en tres actos. Música de Don Rafael Hernando (Madrid: C. González, 1852). See the note under Cosas de Don Juan, above.

Otro diablo predicador, o, El liberal por fuerza. Intermedio dramático para representarse ... con el plausible motivo de la apertura de las Cortes del reino (Madrid: Imprenta de Repullés, 1835). A one-act play with liberals and Carlists.

El pelo de la dehesa. Edited with notes and vocabulary by Joseph Manson. Introduction by J. M. Blair (London: G. Bell and Sons, 1955). A students' edition.

El pelo de la dehesa. Edición de José Montero Padilla (Madrid: Ediciones Cátedra, 1974). Contains a thirty page prologue on Bretón and his comedias.

El plan de un drama, o, La conspiración. Improvisación dramática escrita por dos ingenios de esta corte (Madrid: Imprenta de Repullés, 1835). The two authors are Ventura de la Vega and Bretón. A caricature of a Romantic drama, in which the two conspirators are planning to write a play, not to overthrow the queen!

Le poil de la prairie, comédie en cinq actes, représentée pour la première fois, à Paris, sur le théâtre royal Italien, le 24 avril 1847, par la troupe venue de Madrid, sous la direction de don Juan Lombía, et traduite de l'espagnol par Le Baron Léon D'H. De St-D. (Paris: Imprimerie de Boulé, 1847). The only French translation of a Bretón play I have seen, and the only one listed in the catalogue of the Bibliothèque Nationale.

La ponchada. Improvisación cómica en un acto, escrita por D. Manuel Bretón de los Herreros y D. Julián Romea (Madrid: Imprenta de Yenes, 1840). On October 1, 1840 , the first night of this play, Bretón had to flee the Príncipe theater in fear of his life. The play made fun of the national militia, who pursued him.

¿Quién es ella?, comedia en cinco actos. Edited by Samuel Garner (New York: American Book Company, 1905). A students' edition with footnotes and a SpanishEnglish vocabulary. The introduction describes the misogynist, Don Francisco de Quevedo, the principal character of the play. First staged on December 7, 1849. (The play is also in Obras 1883.)

Resumen de las actas y tareas de la Real Academia Española en el año académico de 1860 a 1861. Leído en la junta pública de 29 de setiembre de 1861 , por el secretario perpetuo de la misma corporación, D. Manuel Bretón de los Herreros (Madrid: Imprenta Nacional, 1861). This was the yearly report Bretón read in public as executive secretary of the Royal Academy of the Language. There are also reports for $1862-1863,1864-1865,1866-1867,1868-1869$. All are listed in Antonio Palau y Dulcet, Manual del librero hispanoamericano, Tomo segundo (Barcelona: A. Palau, 1949), 395-396.

El templo de Himeneo. Melodrama mitológico alegórico, en honor del augusto enlace de nuestro amado soberano Don Fernando VII, con la serenísima infanta de las dos Sicilias, Doña María Cristina de Borbón (Madrid: Imprenta de I. Sancha, 1829). A circumstantial piece, written early in Bretón's career for the wedding of the king. 


\section{Special References}

Bretón de los Herreros, Manuel. "Literatura Dramática. De la Utilidad de la Versificación en los Dramas," in El liceo artístico y literario español, 1838. This is Bretón's Academy entrance speech of June 15, 1837, "Discurso de acción de gracias a la Real Academia Española," minus the exordium and with a "few light changes." (See Obras 1883, i, xlii). A valuable disquisition well worth reading before one starts to read Bretón's plays; in it Bretón tells why he prefers verse to prose in the theater, especially in the comedy, and what meters can best be adapted to dialogue. Many remarks of later critics were inspired by this speech.

Los españoles pintados por si mismos. Por varios autores (Madrid: Gaspar y Roig, Editores, 1851). Contains four artículos de costumbres by Bretón and other articles by many of his contemporaries. One article of this collection, Bretón's El Avisador, is not to be found in the Obras $\mathbf{1 8 8 3}$.

Bretón de los Herreros, Manuel. "Progresos y Estado Actual del Arte de la Declamación en los Teatros de España," in Obras escogidas de don Manuel Bretón de los Herreros, vol. I (Paris: Baudry, 1853). The first half of this book-length essay is a history of the Spanish theater from Juan del Encina (1468? - 1529?) to the 19th century. The second half is a history of the actor's art, declamation. One gathers from Breton that three men were responsible for the reformation of the Spanish theater in the nineteenth century: the playwright Leandro Fernández de Moratín, the actor Isidoro Máiquez, and the impresario Juan de Grimaldi. All subsequent artists are indebted to them.

Ochoa y Ronna, Eugenio. Apuntes para una biblioteca de escritores contemporáneos. Tomo Primero (Paris: Baudry, 1840). Pages 123-131 are Bretón's Academy entrance speech, a version of it to be compared with the first special reference above. The latter, edited for a journal, omits the first five paragraphs of the speech, in which Bretón thanks the Academy for honoring him and confesses his scanty merits. The Ochoa y Ronna version gives the original title of the speech, "Discurso de acción de Gracias a la Real Academia Española," and includes the first five paragraphs; it omits several quotations from Golden Age dramatists and gives act and scene references instead.

“Literatura Dramática. Reseña de un debate sostenido en el Liceo de Madrid," in Revista literaria de El Español, I (1846), 14-16. Bretón, Amador de los Ríos, Rodríguez Rubí, Escosura, Gavino Tejado, and Cándido Nocedal discuss the problem of whether authors of their day can imitate the dramatic poets of the seventeenth century. Bretón, opening the discussion, argues that seventeenth-century authors cannot be taken as models since "the character and customs of Spanish society have undergone a great change;" nevertheless, one can imitate what is good in them and he, Bretón, "has tried to imitate them on many occasions." 


\section{Secondary Sources}

Adams, Nicholson B. "French Influence on the Madrid Theather in 1837," in Estudios dedicados a D. Ramón Menéndez Pidal. Consejo Superior de Investigaciones Científicas, Biblioteca Reyes (Madrid 1950, pp. 135-151). Studies the proportion of foreign and Spanish influences in the theater of the Romantic period.

."The Grotesque in Some Important Spanish Romantic Plays," in Todd Memorial Volumes; Philological Studies, I, 37-46. Among other things, discusses "A Romantic Play by an Anti-Romanticist," the Elena of Bretón.

"Notes on Dramatic Criticism in Madrid: 1828-1833," in Studies in Language and Literature (Chapel Hill: U.N.C. Press, 1945, pp. 231-238). Bretón is "constantly less favorable to Romanticism" than a critic such as Carnerero.

"Notes on Spanish Plays at the Beginning of the Romantic Period," Romanic Review XVII (1926), 128-142. Concludes that even in the hey-day of Romanticism, "the comedy of magic, Scribe's dramatic productions, and the comedy in the style of Bretón de los Herreros " continued steadily.

The Romantic Dramas of García Gutiérrez (New York: Instituto de las Españas, 1922). Chapter II has a succinct history of the Spanish theater in the eighteenth and nineteenth centuries.

."Sidelights on the Spanish Theaters of the Eighteen-Thirties." Hispania, vol. IX (1926), 1-12. Describes the theaters, audiences, salaries, ticket sales, actors and actresses of the 1830's.

Alarcón, Pedro Antonio de. "La Desvergüenza. Poema Joco-Serio de D. Manuel Bretón de los Herreros," in Obras completas, 2a. edición (Madrid: Ediciones Fax, 1954), pp. 1782-1785. Considers this long poem unworthy of Bretón's genius. Nevertheless, it "will serve in future years to show the state of common Spanish speech at the middle of the nineteenth century. Considered in this light, it is no less than a monument."

Alborg, Juan Luis. Historia de la literatura española. Siglo XVIII (Madrid: Gredos, 1972). Pages 593-599 tell the story behind the refundiciones of Trigueros, Solís, Bretón, Hartzenbusch, and others.

Allen, Rupert. "The Romantic Element in Muérete iy verás!", Hispanic Review, XXXIV (1966), 218-227. Argues that the two basic values of Romanticism are love and liberty of action and that these are the values of Pablo and Isabel (and of Bretón) in Muérete iy verás! Says that the play, contrary to the opinion of many critics, satirizes middle class materialism rather than Romantic idealism. Distinguishes between Moratinian restraint, which characterizes the form of Bretón's play, and Romantic morality, which is its content. The play is an "essential Romantic world view" in Moratinian clothing.

Alonso Cortés, Narciso. Bretón de los Herreros. Teatro. Prólogo y notas de Narciso Alonso Cortés. Clásicos castellanos, vol. 92 (Madrid: Espasa-Calpe, 1943). The prologue gives a brief history of the Spanish theater before Bretón and argues that there is a comedia bretoniana consisting in the portrayal of contemporary customs 
from "the little episodes of Spanish life." Discusses the "sober simplicity" of Bretón's style. Reviews the criticism made of his plays.

Amador de los Rios, José. “A Letter to Alberto Lista," in Hans Juretschke, Vida, Obra y

Pensamiento de Alberto Lista (Madrid: Escuela de Historia Moderna, 1951). Says that Bretón, following the Academy, objects to Amador's use of cuádriga as an esdrújula (stress on the antepenultimate).

Asensio, José María. "El Teatro de Don Manuel Bretón de los Herreros," La España Moderna (Madrid, XCVII, 1897), 79-100. Begins as an encomium of Bretón on the centenary of his birth. Examines the criticism of Martínez Villergas, Ferrer del Río, and Larra.

Bacaicoa, Dora. "El Teatro en Tetuán en el año 1860," Revista de Literatura, Tomo III (1953), No. 5-6, 79-98. Bretón's Mi secretario y yo was staged by amateurs in Tetuán, Morocco, in 1860.

Barja, Cesar. Libros y autores modernos. Siglos XVIII y XIX (Los Angeles: Campbell's Book Store, 1933), pp. 141-143, 220. Argues that in Bretón there is an almost constant tendency towards exaggeration and caricature, "to the point of making the characters true types from the comedia de figurón."

Blasco, Eusebio. "Las Costumbres en el Teatro: Su Influencia Recíproca," in La España del Siglo XIX, Curso de 1886-1887, Vol. III, 121-171 (Ateneo Científico, Literario y Artístico de Madrid). Argues that customs make the theater; the theater does not influence customs. Discusses the position of Vega, Bretón, Serra and López de Ayala in the nineteenth century theater. Has a most high opinion of Bretón.

Bretón y Orozco, Cándido. Breve noticia de la Biblioteca Nacional (Madrid: Imprenta de Aribau y Cía., 1876). A thirty-five page booklet, by the nephew of Bretón, describing the history, collections, work and famous persons of the National Library. Bretón became director of the Library in 1847 , and in 1858 he instituted an annual director's memoire.

Brown, Reginald F.“Three Madrid Periodicals: La Abeja, Eco del Comercio, El Español," in First Liverpool Studies in Spanish Literature (Liverpool: Institute of Hispanic Studies, 1940), pp. 44-79. Discusses the periodical literature of Bretón's day. Says that the "standards of the Abeja seem to have been those of Bretón, himself probably its most representative figure." In arguments over classicism and romanticism Bretón represents the middle way.

Brunetière, Ferdinand. Brunetière's Essays in French Literature (New York: Scribner's, 1898). Some of his ideas on Molière are applicable to Bretón; see p. 66.

Burgos, Carmen de ("Colombine"). Fígaro (Madrid: Imprenta de "Alrededor del Mundo," 1919). Chapter XIV, "Larra y Bretón," discusses the famous misunderstanding and later reconciliation of the two authors. Speaks well of Larra and ill of Bretón. Argues that Molíns was guilty of "lamentable partiality" in his biography of Bretón.

Calderón, Fernando. A ninguna de las tres (México: Editorial Porrúa, 1972). The Mexican, Calderón (1809-1845) writes an imitation of Bretón's Marcela ¿a cuál de los tres? The roles are reversed. A young gentleman, Don Juan, rejects the three 
superficial daughters of a middle class family. The fop, Don Carlos, tries to be more French than Mexican.

Campo, Agustín del. "Sobre la Marcela de Bretón," Berceo, II (1947) 41-55. Shows the development of the Spanish comedia from Moratín to Bretón. Argues that Bretón removes the comedia from "Moratinian uniformity."

Campos, Jorge. Teatro y sociedad en España (1780-1820) (Madrid: Editorial Moneda y Crédito, 1969). See the two sections, "Clase Media y Familia," and "Una nueva clase en escena," pp. 95-108. Argues that the middle class appeared in "the theater of the Enlightenment, in Moratín, in Cadalso's Cartas and even in Comella. "It's a new class which comes forth on the stage with its problems."

Carr, Raymond. Spain, 1808-1939 (Oxford, 1966). An outstanding history of nineteenth-century Spain.

Cejador y Frauca, Julio. Historia de la lengua y literatura castellana (Madrid: Tip. de la Revista de Archivos, 1918), vol. VI, 405-415. Sees Bretón "breaking the narrow molds of Moratín" and restoring the national theater. Says that many liken Bretón to Scribe but the comparison is incomplete for he surpasses Scribe with his fine satire, his Castilian wryness, his fresh imagination and wit, and his mastery of versification. ... Bretón is the Spaniard who has used the greatest number of words, and in this, as in so many things, he is unlike Moratín. "One can say in general he is the greatest comic of the Spanish theater, certain pleasantries of Tirso set aside."

Cervera y Jiménez-Alfaro, Francisco. "Bretón en el siglo XX y en la intimidad," in Berceo II (1947), 11-15. Describes Bretón's theater through the eyes of Don Juan Valera and Gerardo Diego. Mentions his influence in Mexico and Peru. Introduces his epistolario.

Chaskin, Silvia Novo Blankenship. Social Satire in the Works of Manuel Bretón de los Herreros. Doctoral dissertation, University of Virginia, 1968. (Ann Arbor: University Microfilms, 1969). This entry appears in the J.A. Corey dissertation under the name Blankenship. Shows the ultimate seriousness of the Bretonian comedy. After Molín's biography of 1883 and Le Gentil's study of 1909, this dissertation is the most complete study of Bretón's theater.

Chaulié, Dionisio. Cosas de Madrid. Apuntes sociales de la villa y corte (Madrid: M.G. Hernández, 1884). Pages 221-229 and 275-279 throw light on the theater and censorship of 1820-1840.

Chaves, Manuel. Bocetos de una época (1820-1840) (Madrid: Librería de Fernando Fe, 1892). Twenty-four sketches concerning persons and events from 1820 to 1840 . Emphasizes Fernando VII and the Carlist War.

Consiglio, Carlo. "Algunas Comedias de Bretón de los Herreros y Sus Relaciones con Goldoni.” Berceo II (1947), 137-145. Argues that Goldoni's La Locandiera and La vedova scaltra are probable sources of Bretón's Un novio para la niña and Marcela.

Cook, John A. Neo-Classic Drama in Spain (Dallas: Southern Methodist U. Press, 1959). Chapter XVI, "The Last Stage of Neo-Classic Drama," includes Gil y Zárate, Bretón, Flores y Arenas, and Ventura de la Vega. Argues that "Bretón is credited with a far greater deviation from neo-classic precepts than an examination of his comedies reveals." 
Corey, James Alan. The Comedies of Manuel Bretón de los Herreros. Doctoral Dissertation, UCLA, 1972 (Ann Arbor: University Microfilms, 1973). Argues that Bretón, "a mediocre dramatist," was the only successful neo-classic writer left in Spain. Has a long bibliography.

Cortada, Juan. Historia de España desde los tiempos más remotos hasta 1839 (Barcelona: Imprenta de A. Brusi, 1841). Describes the death of Ferdinand IV and explains how he got his name El Emplazado (pp. 75-76). Argues that no man should question whether Don Fernando's death was by chance or a punishment of heaven "because the judgements of God are inscrutable for all."... Bretón's play, Don Fernando el Emplazado, was first staged in 1837. It is interesting to note that as late as 1841, the year Cortada's book appeared, there were historians who still accepted the legend or at least did not question it. (The historian Antonio Benavides accepted the legend as late as 1860: see the Diccionario de historia de España, Madrid: Revista de Occidente, I, 1952, pp. 1123-1124.)

Cossío, José María de. "Correspondencias literarias del siglo XIX en la Biblioteca de Menéndez y Pelayo," in Boletín de la Biblioteca Menéndez y Pelayo, XIII (1931), 360-370. Contains ten short letters, dated from 1849 to 1864, from Bretón to Manuel Cañete, the theater critic, and one letter to the Conde de San Luis, Sartorius. Cañete has indicated he would like to enter the Academy.... Bretón asks for a job for someone he knows; and he asks the Conde de San Luis to support the sale of his books. (Since this letter is dated 1850 it probably refers to the $1850-1851$ edition of his Obras.)

Díaz-Plaja, Fernando. La vida española en el siglo XIX (Madrid: Afrodisio Aguado, 1952). Describes Spanish life in the nineteenth century. Takes many passages from Larra, Bretón, Galdós, and others. "What Larra condemns Bretón de los Herreros describes in a pleasant, cheerful way, in order to adorn his plays and give them atmosphere" (p. 10).

Díaz-Plaja, Guillermo. "Conmemoración de Bretón de los Herreros," in La Voz Iluminada, 1952, pp. 155-177. Written in 1946, this general essay commemorates the 150 th anniversary of Bretón's birth. "Today his creative mode leaves us absolutely indifferent."

Duffey, Frank M. "Juan de Grimaldi and the Madrid Stage (1823-1837)", Hispanic Review, X (1942), 147-156. Argues that between 1823 and 1837 Grimaldi helped in "maintaining and increasing the faint spark of life in the Madrid theater," and that his association with Bretón is particularly interesting."

Escobar, José. "Sobre la formación del artículo de costumbres", Boletín de la Real Academia Española, 50 (1970), 559-573. Several references to Bretón's costumbrismo. Note 17 cites two articles, "Todo es farsa en este mundo" and "Sobre la risa" not contained in the Obra dispersa. These two articles appear in the Correo Literario y Mercantil, núm. 175, 24 de agosto de 1829, and núm. 180, 4 de sept. de 1829. 
Fastenrath, Johannes. Lustspiele von Don Manuel Bretón de los Herreros. Deutsch von Johannes Fastenrath (Dresden: Verlag von Carl Reissner, 1897). The German Hispanophile, Fastenrath, translated four of Bretón's plays for this book and wrote a good, succinct, entertaining prologue. Bretón, he says, "was swinging Menander's whip but without Aristophanes' choler."

Ferrer del Río, Antonio. Galería de la literatura española (Madrid: Establecimiento tipográfico de Mellado, 1846), pp. 127-140. A factual essay concerning Bretón. Lists his works. Contains similar essays on a dozen of his contemporaries. Says that the satirical verses of "Contra el furor filarmónico" is a faithful portrait of what went on in Bretón's day.

Figarola-Caneda, Domingo. Gertrudis Gómez de Avellaneda (Madrid: Sociedad General Española de Librería, 1929). Page 126 has a letter dated October 31, 1845 from Bretón to la Avellaneda, who had asked him to collaborate in a journal edited by ladies, "amables poetisas." He says he will not be a "useless drone in that pretty republic of discreet and beautiful bees."

Ford, Richard. A Hand-Book for Travelers in Spain. I (Carbondale, Illinois: Southern Illinois University Press, 1966). Describes the theaters, music and dance of Bretón's day (pp. 282-288). Explains the various parts of the theater house. Only men were admitted to the pit, only women to the cazuela.

Gabbert, Thomas A. "Notes on the Popularity of the Dramas of Victor Hugo in Spain During the Years 1835-1845," Hispanic Review, IV (1936), 176-178. Notes that in Spain "the most enduring success did not fall to the lot of Hugo's better plays ... but to such popular prose melodramas as Lucrèce Borgia and Angelo.

García Castañeda, Salvador. "Juan Martínez Villergas y un cuadro de Esquivel," Revista de Estudios Hispánicos (Alabama), vol. VII (1973), 179-192. Three pages explain the attacks of Villergas on Bretón: “. . . it seems that amongst his contemporaries Bretón was noted for being egoistic and free with his mirth." When reading this article the reader should also consult J. Chastenay, "Une epigramme de Martínez Villergas," Revue Hispanique, XVIII (1908), 286-287, and XXII (1910), 453-456. This is the epigram in which Villergas makes fun of Bretón's eye, and: “. . . a snake bit Bretón./ Did Bretón die? No, to be sure;/ the snake did."

García Prado, Justiniano. "Bretón y su patria chica," Berceo, II (1947), 57-62. Describes the town of Quel, where Bretón was born and lived until ten years of age. Cites Bretón's article El Matrimonio de Piedra."

Gil y Zárate, Antonio. "D. Manuel Bretón de los Herreros," in Nicomedes Pastor Díaz, Galería de españoles célebres contemporáneos (Madrid: Imprenta de Sánchez, 1841), pp. 1-53. A biography of Bretón by a famous contemporary dramatist. Gives a good account of what the Spanish theater was like when Bretón began to write. Throws light on the censorship of the time. Discusses at lenght Bretón's poesías sueltas, e.g., his sátiras en tercetos and letrillas.

Goenaga, Angel and Maguna, Juan P. Teatro español del siglo XIX, análisis de obras (Long Island City: Las Américas, 1972). Contains a forty page analysis of Muérete iy verás!. 
Herrero Salgado, Felix. Cartelera teatral madrileña II: años 1840-1849 (Madrid:C.S.I.C., 1963). The plays staged from 1840 to 1849 . In the number of entries, Bretón is first, Scribe second, Vega (as translator) third, with Ramón de la Cruz and Tomás Rodríguez Rubí after them.

Howell, Stanley E. "Does Bretón's Marcela Stem from Quijote," Modern Language Notes, LIII (1938), 195-196. Argues that the heroine of Marcela was suggested to Bretón by the disdainful shepherdess, Marcela, in Don Quijote.

Inglis, Henry David. Spain: In two volumes (London: Whittaker and Co., 1837). This is the second and revised edition of Spain in 1830. An observant Englishman writes his impressions of Spain in 1830, when Ferdinand VII still reigned. This corresponds to the early years of Bretón's theater. Chapter III discusses the theater, Chapter VIII, literature.

Iravedra, Luisa. "Las Figuras Femeninas del Teatro de Bretón," Berceo II (1947), 17-24. Argues that in Bretón's plays the figure of a woman always dominates the other characters. His females do not follow the "soft obedient line" of the women of Moratín but "in their ease and outgoingness are like some of the women in our classical theater." Even Bretón's comic servants are female rather than male, so much do women stand out in his plays. Speaks of the escarceo (prancing) of Marcela's three suitors.

José Prades, Juana de. "El teatro de Lope de Vega en los años románticos," Revista de literatura XVIII (1960), 235-248. Shows that the theater of the 1830's was "a most curious and heterogeneous mosaic." Lope's plays were popular alongside Romantic dramas, neo-classic dramas, the theater of Ramón de la Cruz, foreign works in translation, Italian operas and the comedias of the Golden Age. The attraction of Lope's theater was owing in part to the adapters, one of whom was Bretón.

Kennedy, James, Modern Poets and Poetry of Spain (London: Longman, Brown, Green, 1852). One of the few places Bretón is to be found in translation. On pages 258-264 three letrillas are rendered into English. (The Library of Congress copy is missing pages 225-254, which contain some of Bretón's poetry.)

Lafuente, Modesto. Teatro social del siglo XIX por Fray Gerundio. 2 vols. (Madrid: Establ. Tipográfico de Mellado, 1846). The humorous articles of Lafuente (1806-1866) are similar to many plays of Bretón, and the motto he writes on his title page ("Casi siempre riendo,/ pocas veces llorando,/ corregir las costumbres deleitando.") might be taken as the motto of Bretonian comedy.

Larra, Fernando José de. La sociedad española a través del teatro del siglo XIX (Madrid: Ministerio de Trabajo, 1947). Throws some light on four plays of Bretón.

Larra, Mariano José de. Artículos de crítica literaria y artística, vol. 52 of the series Clásicos castellanos (Madrid: Espasa-Calpe, 1950). Contains many essays concerning the theater of Bretón's day. One, a review of Bretón's Un tercero en discordia, has an idea which many other critics have repeated, viz, the thought that Bretón was an outstanding talent who did not pay attention to depth. 
Le Gentil, Georges. Le Poète Manuel Bretón de los Herreros et la Société Espagnole de 1830 à 1860 (Paris: Hachette, 1909). An outstanding work of criticism. Le Gentil is the first of all Bretonian critics. His book might be read at the same time one reads Molíns's biography.

Leslie, John Kenneth. Ventura de la Vega and the Spanish Theatre, 1820-1865 (Princeton: Univ. Press, 1940). Many ideas of this book can be applied to Bretón. Pages 50-52 argue that Vega and Bretón translated Romantic dramas only as potboilers; they really disdained Romantic dramas.... An interesting note: Vega acted in the plays of Bretón and Moratín.

Lincoln, J.N. "A Note on the Indebtedness of Pereda's La Puchera to Bretón's La Independencia." Hispanic Review, XI (1943), 260-263. Argues from identical characterization, parallel plot and similarities in language that Pereda's characters Marcones and La Galusa were based on Bretón's Jesual do and Nicanora.

López Serrano, Matilde. "Comienzos de Bretón Como Bibliotecario," Berceo II (1947), 7-9. Shows how Bretón gained the post of second librarian in the National Library.

Lorenz, Charlotte M. "Translated Plays in Madrid Theatres (1808-1818)," Hispanic Review, IX (1941), 376-382. Argues that contrary to the opinion of many critics, translations did not outnumber originals in public theaters. They accounted for less than a third of the performances. Gives many statistics.

Lovett, Gabriel. "Francophobia in Nineteenth Century Spanish Letters," Kentucky Romance Quarterly, XIX (1972), 285-299. Francophobia was caused by memories of the 2 de mayo and by "French misconceptions and misrepresentations concerning the Spanish character." Some patriots reacted indignantly, but "merry satire also had its day," e.g., Bretón's Un francés en Cartagena (1843), in which Gustavo de Martignac tries to enter a Spanish house via the balcony, for he believes that is the custom. See Le G., 249, where Le Gentil discusses gallomania, gallophobia, and "systematic traditionalism."

Lozano Guirao, Pilar. "El Archivo Epistolar de don Ventura de la Vega," Revista de literatura, Madrid, XIII (1958), 121-172. Contains four letters from Bretón to his close friend, Vega. Also seventy other letters, to and from Vega.

Martínez Cachero, José María. "Una Velada Necrológica. Homenaje a Bretón de los Herreros," Berceo VIII (1953), 545-556. Describes the activities in commemoration of Bretón the night of December 17, 1873. Reproduces the loa of the poet Emilio Ferrari.

Martínez Ruiz, José (“Azorín"). "Los Hermanos Quintero," in La Farándula, in his Obras completas (Madrid: Aguilar, 1962), VII, 1181-1182. Praises Bretón’s comic muse, but "in the poetic world of Breton, something is lacking; that something is the feeling of an ideality, of a spiritual state superior to what is earthly and perishable." Ranks the Quintero brothers higher than him.

Los Quinteros y otras páginas, in Obras completas (Madrid: Aguilar, 1961), IV, 624-626. Makes a favorable judgement of Bretón. Gives him a central position in the development of the Spanish theater. 
Rivas y Larra. Razón social del romanticismo en España, in Obras completas (Madrid: Aguilar, 1961), III, 485-516. Has a low opinion of Bretón: "Nothing so superficial, incongruous and absurd as the theater of Bretón. The only thing admirable in Bretón is the versifying faculty, the marvelous facility to write prose in verse" (p. 516). Azorín also writes: "Larra was annoyed at Bretón: there was no reason for being so; the comedy of Bretón, infantile and absurd, could not ruffle an intelligent man like Larra" (p. 513). This scornful judgement of Azorín has caused perhaps the critical neglect of Bretón in the 20th century. One must beware of post hoc ergo propter hoc arguments, but Chapter XIV of Carmen de Burgos's 1919 biography of Larra, Fígaro, will show the enormous influence of a writer like Azorín.

Martínez Villergas, Juan. Juicio crítico de los poetas españoles contemporáneos (París: Librería de Rosa y Bouret, 1954). Has one important insight concerning the criticism of Bretón: "There is one prejudice in my country which should be destroyed [...] that of looking upon festive works disdainfully even when they have merit, and of reserving praise for serious and pompous compositions although, as Prudhoun says, they may disguise their emptiness of thought with high-blown words. [...] we see mediocre men [...] scorn all inspiration which adopts a festive form, and they say in a haughty tone : "That has an alehouse style" (see pp. 24-28). Some critics, Azorín among them, could not forgive Bretón his festive ways or "alehouse style."

Mazade, Ch. de. "La comédie moderne en Espagne: Bretón de los Herreros, Ventura de la Vega, Rodríguez Rubi," Revue des Deux Mondes, Paris, XIX (1847), 432-461. Argues for a double influence in the renaissance of the theater in the early nineteenth century: (1) a desire to revive the originality of the Golden Age comedia, and (2) a desire to overcome the literary dominance of France in Spain. Says that after France the theater is more flourishing in Spain than any other country. Sees a "visible incertitude" in the efforts of the new comediographers, Bretón, Vega, and Rodríguez Rubí.

Menéndez Pelayo, Marcelino. Antología General de Menéndez Pelayo (Madrid: Biblioteca de Autores Cristianos, 1956), II, 945-946. Argues that Bretón is the most marvelous versifier since Lope de Vega; that he portrays the middle class of his time, though often in caricature; that his one grave defect is superficiality; and that he is the last of a line of satirizers dating back to Hervas in the eighteenth century. Speaks of Bretón's eclecticism.

Mesonero Romanos, Ramón de. "Los Autores Dramáticos de 1836 a 1843," La Ilustración Española y Americana, 15 September 1881, p. 151. Contains an important note on Scribe and the "drama de costumbres políticas". Says the "género bretoniano" consists of "comedias de costumbres privadas".

Molíns, Marqués de. Bretón de los Herreros. Recuerdos de su vida y de sus obras (Madrid: Imprenta de M. Tello, 1883). The story of Bretón by his close friend and fellow Academician, Mariano Roca de Togores, Marqués de Molíns. An outstanding biography; one might say that Molíns follows the thoughts of Boswell in his Life of Samuel Johnson: "Wherever narrative is necessary to explain, connect, and supply, I 
furnish it to the best of my abilities; but in the chronological series of Johnson's (Breton's) life, which I trace as distinctly as I can, year by year, I produce, wherever it is in my power, his own minutes, letters, or conversation, being convinced that this mode is more lively, and will make readers better acquainted with him (...) And he will be seen as he really was; for I profess to write, not his panegyric, which must be all praise, but his Life, which, great and good as he was, must not be supposed to be entirely perfect. (...) In every picture there should be shade as well as light." Molíns's biography is what Leon Edel calls "the chronicle life": see Edel, Literary Biography (Bloomington: Indiana U. Press, 1973), pp. 125-126 of Chapter 5.

"Don Manuel Bretón de los Herreros," in Novo y Colson, P. de, Autores Dramáticos Contemporáneos, Tomo II (Madrid: Imprenta de Fortanet, 1882), 147-162. A succinct biography of Bretón.

Morley, S. Griswold. "The Curious Phenomenon of Spanish Verse Drama," Bulletin Hispanique, vol. 50 (1948), 445-462. Argues that Spain alone among European Nations has a long tradition of entire plays, "romantic or realistic," being written in short meters "invented for and best employed in lyrics." Traces the use of verse and prose in the Spanish theater from medieval times to García Lorca. Should be read at the same time as Bretón's Academy speech.

Navarrete, Ramón de. "Recuerdos. El Obispo de Mallorca y D. Manuel Bretón de los Herreros,” La Ilustración Española y Americana,” 1873, pp. 727-730. Says Bretón did not know the meaning of envy. Gives the background of ¿Quién es ella? Says that Bretón's versification was not as natural and easy as it seems: "Bretón showed me a notebook literally covered with corrections and words scratched out." "Bretón was the poet who "began the resurrection of our theater." Page 730 also has a sonnet by Alarcón, "En la tumba de Bretón de los Herreros."

Nervo, Amado. "Un tercero en discordia," in Obras completas, I, Cuarta edición (Madrid: Editorial Aguilar, 1967), 476-477. A Mexican poet's brief review of an 1895 performance of Un tercero en discordia.

O'Brien, Robert. Spanish Plays in English Translation (New York: Las Américas, 1963). Lists one translation in English of Bretón, his one-act play Una de tantas: "One of Many",translated by Willis K. Jones in Spanish One Act Plays in English, ed. by W. K. Jones, Dallas: Tardy, 1934." I know of no other play by Bretón translated into English.

Parker, Adelaide (and E. Allison Peers). "The Influence of Victor Hugo on Spanish Poetry and Prose Fiction," Modern Language Review, XXVIII (1933), 50-61. Argues that Hugo was more a vogue than an influence in Spain. Shows that one of Bretón's letrillas is an imitation of Hugo.

"The Influence of Victor Hugo on Spanish Drama," Modern Language Review, XXVIII (1933), 205-216. Bretón wrote two plays in which Hugo's influence might be looked for, Elena and Don Fernando el Emplazado. On the whole, Hugo's influence on "the six principal Spanish writers" of 1834-1837 was small. 
"The Vogue of Victor Hugo in Spain," Modern Language Review, XXVII (1932), 36-57. The first of three articles arguing that Hugo was more a vogue (a kind of general influence), than a penetrating influence in Spain in the 1830's and 1840 's. Has several references to Bretón and speaks of his eclecticism.

Peak, J. Hunter. Social Drama in Nineteenth-Century Spain. University of North Carolina Studies in the Romance Languages and Literatures, Number 51 (Chapel Hill: Univ. of N.C. Press, 1964) pp. 41-43. Argues that Martínez de la Rosa, Gorostiza, Bretón and Ventura de la Vega are the most important playwrights to continue the Moratinian tradition. Sees some "thesis elements" in plays such as A Madrid Me Vuelvo, in which a character like Bernard is "something of a raisonneur;" nevertheless, Bretón's main purpose is to amuse.

Peers, E. Allison. "Literary Ideas in Spain From 1839 to 1854," Modern Language Review, XXI (1926), 44-54. Argues that 1839 to 1854 were years of an ill-defined literary eclectism in Spain. Classicism and Romanticism were both under suspicion. In the theater the outlook was bleak. The dramas, many of which were not originals but translations, were barren and the theaters often empty. At this time Patricio de la Escosura could write: "What is left? Bretón, with his facile, fluid, sonorous, most pleasant verses $[\ldots]$ but Bretón is only one man and his productions are not enough to satisfy the hunger the public has for new things [...]"

"The Vogue of Alexandre Dumas Père in Spain 1830-1842" in Homenatge a AntonioRubio i Lluch. (Barcelona: 1936), I, 553-578. Discusses the translations of Hugo and Dumas père in the Spanish theater. Distinghishes between the vogue and the influence of foreign works. Dumas's plays were a vogue in Spain.

Piferrer y Fábregas Pablo. Estudios de crítica. Colección de artículos escogidos (Barcelona: Diario de Barcelona 1859). Contais forty-eight review articles, five of them on Bretón's plays: Lo vivo y lo pintado, Flaquezas ministeriales, Los hijos de Eduardo (a translation), Dios los cría y ellos se juntan, and Un novio a pedir de boca. Many other articles concern the theater and opera of Bretón's day.

Piñeyro, Enrique. El romanticismo en España (Paris: Garnier, 1904). Contains a twenty page essay on Bretón's life and work.

Qualia, Charles B. "Dramatic Criticism in the Comedies of Bretón de los Herreros," Hispania, XXIV (1941), 71-78. Discusses the influence of Moratín's El sí de las ninas on the literary criticism found in Bretón's comedies. Argues that Bretón was an advocate of balance, common sense, the just means, in a world, lo clásico.

Comedia, 1737-1800." PMLA, LIV (1939, No. 1), 184-211. For the neo-classicists the traditional comedia of Spain was a "national disgrace." They opposed it and also the autos sacramentales on grounds of literary theory and morality. Spain did not have "good taste," it was not a cultured nation, and so they were ashamed. The Spanish stage should be reformed through neo-classical drama, especially tragedy. Finally, in 1799 and 1800 , the neo-classicists resorted to government coercion and censorship, but the Spanish people deserted the theater houses. The comedia survived the assault of the intellectuals. 
Rodríguez Cepeda, Enrique. "Problemas del Teatro en 1800 y un Documentc Inédito de Isidoro Máiquez," Revista de Occidente, XXIX (Junio, 1970, No. 87), 357.364. Discusses the social position of the theater in the 17th and 18th centuries. Argues that Máiquez by his imposing presence reformed the theater, not only in its acting, but in its contracts, salaries, norms and laws. Before, him, actors learned their art "by a false professional experience." Reproduces his letter requesting leave to go to France, where he studied with Talma.

Rogers, Paul Patrick. "Dramatic Copyright in Spain Before 1850," The Romanic Review, XXV (1934), 35-39. Shows the lack of copyright protection given to dramatists down to 1849 . Writers were defrauded financially, and even aesthetically, for their characters, titles and speeches were frequently changed without their knowledge. In 1832 Bretón received a flat 1,000 or 1,500 reales for a comedy; for printing a play, ceding it to the editor, he received 500 reales.

(1930), 315-324. Discusses the Spanish drama from 1800 to 1833 , during which period the old national theater struggled with the neo-classic. Sees some authors, notably Bretón, combining the virtues of both groups. Argues that the numerous translations of this period were good for the theater and for Spain; they meant new ideas, new form, new methods and, ultimately, new life.

"The Peninsula War as a source of Inspiration in the Spanish Drama of 1808-1814," Philological Quarterly VIII (1929), 264-269. Lists the patriotic plays that appeared during the Napoleonic invasion. Shows that translations from the French were numerous before and after the war but not during it.

Rubio, Federico. Mis maestros y mi educación. Memorias de niñez y juventud. (Madrid: Fernando Fe, 1912). Outstanding memoirs concerning the years 1827-1850. A forgotten masterpiece, this work should be republished.

Ruiz Ramón, Francisco. Historia del teatro español (Madrid: Alianza Editorial, 1967), pp. 440-443. Argues that, paradoxically, we get a better picture of Romantic Spain from Bretón's theater than from Romantic theater such as Don Alvaro.

Rumeau, A. "Le Théâtre à Madrid à la Veille du Romantisme, 1831-1834,"' in Hommage a Ernest Martinenche. Etudes Hispaniques et Americaines (Paris: Editions Arbrey, 1939), pp. 330-346. Carefully describes the theater between 1831 and 1834.

Sancho y Gil, Faustino. Elogio de don Manuel Bretón de los Herreros (Zaragoza: La Derecha, 1886). This rare book cannot be borrowed from the Biblioteca Nacional in Madrid. I have not seen it.

Shields, Archibald Kenneth. The Madrid Stage 1820-1833. Unpublished doctoral dissertation, University of North Carolina, Chapel Hill, 1933. 3 volumes. Using newspapers as its sources, lists all the plays presented at the Príncipe and Cruz theaters between 1820 and 1833 .

Simón Diaz, José. Cartelera teatral madrileña, I: años 1830-1839 (Madrid: C.S.I.C., 1961). An index of the plays presented in Madrid from 1830 to 1839. The list of authors shows Bretón and Scribe outrunning by far all other playwrights. 
"El Epistolario. Cartas a B.S. Castellano, Cartas a Navarro Villoslada, \& C.," Berceo, II, Logroño, 1947, 28-40. Contains nineteen letters, from Bretón, his wife and several contemporaries, between 1841 and 1862.

1947, 25-28. Indicates many untapped sources in the press for studying Bretón.

Smith, W. F. "Rodríguez Rubí and the Dramatic Reforms of 1849," Hispanic Review, XVI (1948), 311-320. Shows that tha theatrical reforms of 1849 , a sincere effort to correct certain recognized evils, were frustrated by Rodríguez Rubí even though he himself favored them and directed them. He seduced the public taste with the "romantic sentimentalism" of his plays, and the public was unsympathetic to the reforms. There was "a dearth of good plays." Throws light on the theater of 1840-1855. Says "this recrudescence of the drama pasional led to the outmoding of the Bretón type of comedia."

Stoudemire, Sterling A. “Dionisio Solís's Refundiciones of Plays (1800-1834)," Hispanic Review, VIII (1940), 305-310. Solís rewrote many Spanish plays of the Golden Age for the audiences of his day. He was "one of the few who waged a successful fight to bring to the Spanish people their own great works in a time when translations, operas, and other things non-Spanish were largely the fashion." Gives many statistics concerning performances.

"Gil y Zárate's Translations of French Plays," Modern Language Notes XLVIII (1933), 321-325. Explains that arreglada (arranged, or adapted) and traducida (translated) have no constant meaning. A play "adapted from the French" may be a literal translation, or such a free adaptation that it is more like a new play. Similarly, a play "translated from the French" may really be an adaptation.

"Metastasio in Spain," Hispanic Review, IX (1941), 184-191. Shows the influence of the Italian opera in Spain down to 1810.

Tamayo y Baus, Manuel. Obras completas (Madrid: Editorial Fax, 1947). In his Royal Academy speech, on pp. 1160-1161, Tamayo discusses Bretón's A Madrid me vuelvo and Vega's El hombre de mundo.

Valbuena Prat, Angel. Historia del teatro español (Barcelona: Editorial Noguer, 1956). Says that Bretón's "true terrain" is that of dramatic costumbrismo, between the tradition of Moratín and the realistic touches of Ramón de la Cruz.

Valera, Juan. Obras completas, II (Madrid: Aguilar 1961), 1272-1277. Argues that Bretón's theater can be summed up in the phrase a la pata la llana (plainly, unaffectedly). He portrayed what he saw. Gives a good description of the Madrid of Bretón's day. Pp. 1249-1375 contain essays on a score of Bretón's contemporaries. Another criticism by Valera can be seen in the Cejador y Frauca Historia, vol. VI, 411-413, which is cited above in this Selected Bibliography.

Vega, Ventura de la. "Don Manuel Bretón de los Herreros," in Museo de las Familias: Lecturas Agradables e Instructivas, I (1843), 9-10. The author, a famous playwright and close friend of Bretón, praises him and defends him against certain charges. Has some material of anecdotal value. 
Wallis, Severn Treackle. Spain. Her Institutions, Politics and Public Men. A Sketch. (Boston: Ticknor, Reed and Fields, 1853). A series of delightful observations by an American traveler to Spain. Chapter IX discusses newspapers, Chapter XIX theaters and dramatic literature, and Chapter XX literature. Has an account of Bretón's ¿Quién es ella? (pp. 211-213) and Rubís Isabel la Católica (pp. 213-216).

University of Wisconsin-Milwaukee 